This is an electronic version of an article published in Bencze, J. L., \& Bowen, G. M. (2009). A national science fair: Exhibiting support for the knowledge economy. International Journal of Science Education, 31(18), 2459-2483. Cognition and Instruction is available online at: www.tandfonline.com<http://www.tandfonline.com/> with http://www.tandfonline.com/openurl?genre=article\&issn=0950-0693\&volume=31\&issue $=18 \&$ spage $=2459$

Please note that tables/figures that are referred to in this article are not available on the post-print version. For the full article with tables/figures please click on the link above.

\title{
A National Science Fair: \\ Exhibiting Support for the Knowledge Economy
}

\begin{abstract}
Student-directed, open-ended scientific investigations and invention projects may serve to deepen and broaden students' scientific and technological literacy and, in so doing, enable them to succeed in democracies greatly affected by processes and products of science and technology. Science fairs, events at which student-led projects are evaluated and celebrated, could contribute to such positive personal and social outcomes. Qualitative data drawn from a national science fair over succeeding years indicate (after analyses of largely qualitative data, using constant comparative methods) that, apart from positive outcomes regarding science literacy, there may be some significant issues about the fair that warrant critical review. It is apparent from these studies that there are issues of access, image and recruitment associated with the fair. Qualification for participation in the fair appears to favour students from advantaged, resource-rich backgrounds. Although these students do benefit in a number of ways from the fair experience, it is apparent that science fairs also greatly benefit sponsors - who can, in a sense, use science fairs for promotional and recruitment purposes. These findings and claims raised, for us, some important questions possibly having implications for science education and for society more generally.
\end{abstract}




\section{INTRODUCTION}

Science fairs, events at which students display and discuss summaries of their projects in mathematics, science and/or engineering, have a long tradition in many jurisdictions around the world. Given that science fairs promote student-led project work, which tends to be de-emphasized in schools, they may be viewed as positive educational phenomena. Through such projects, students can, for example, develop expertise and confidence for solving problems, learn about the nature of problem solving, and develop conceptions of phenomena about which they are investigating. There is, however, a relatively small body of peer-reviewed literature relating to science fairs. Moreover, much of this literature base is confined to phenomena within fairs - including, for example, the nature of judging and the nature of students' projects. Little research has been conducted into larger societal issues pertaining to science fairs — an area of research that seems important, given that science fairs often function on the boundaries between schooling and general society. In this paper, therefore, we report summaries of our studies of successive versions of a national science fair and, then, relate our findings to broader societal conditions.

This paper begins with a review of the role of project work in schools and follows that with a summary of educational literature regarding science fairs. These reviews set the stage for our study of a national science fair in terms of its position in the schooling-society nexus. Our analyses suggest that the science fair under study seems to function in ways that lend support for the concept/movement sometimes referred to as the knowledge economy. These functions, we suggest, may benefit controllers of knowledge production and distribution — but may not, necessarily, benefit all students.

\section{DOING SCIENCE IN SCHOOLS}

Worldwide, governments produce curriculum guidelines that provide school systems with a mandate to help students develop 'scientific literacy' (e.g. DfEE, 1999; NRC, 1996). Although widely agreedupon definitions of such literacy are elusive, many curricula prioritize learning in each of the following three broad domains; that is, for learning:

- 'Science': That is, products of science and technology, including laws, theories and inventions.

- 'About Science': That is, learning ideas about: i) the nature of science (and technology), ii) methods used for science inquiry and technology design, and iii) positive and negative relationships amongst fields of science and technology and societies and environments. 
- To 'Do Science': That is, expertise, confidence and motivation - much of which appears to be tacit — required to develop and communicate knowledge in science and technology (Hodson, 1998).

This is a very comprehensive conception of literacy in science and technology. Students educated in such ways would be well-prepared to lead personally fulfilling and socially/environmentally responsible lives. They might, for example, be able to conduct science or invention projects in their personal lives and more critically evaluate claims and products of professional science and technology.

For various and often complex reasons, however, school science systems - comprised, for example, of governments, community members, parents, businesses (e.g. textbook publishers), teacher preparation institutions and teachers - tend to emphasize teaching and learning of 'science', at the expense of learning in the other two domains (Chinn \& Malhotra, 2002; Désautels, Fleury \& Garrison, 2002; Eisenhart, Finkel \& Marion, 1996). Although programmes to enhance teachers' perspectives 'about science' have shown promise, teachers often tend to de-emphasize (Lederman, 1999) and/or misrepresent the nature of science (Hodson, 1999). Among approaches that can lead to such problems of representation are guided science 'inquiry' tasks, which are organized, ultimately, to lead students towards acceptance of laws and theories of professional science. The National Research Council (2000) in the USA, for example, clearly encourages teachers to link the learning of 'science' with learning 'about science' and 'doing science':

The term 'inquiry' is used in two different ways in the Standards. First, it refers to the abilities students should develop to be able to design and conduct scientific investigations and to the understandings they should gain about the nature of scientific inquiry. Second, it refers to the teaching and learning strategies that enable scientific concepts to be mastered through investigations. In this way, the Standards draw connections between learning science, learning to do science, and learning about science (NRC, 2000, p. Xv).

Where the goal of inquiry tasks is to ensure that students' conclusions correspond with those of professional science and technology, teachers often must regulate students' topics, goals, methods, approaches to data analysis and ways of depicting data. Regulation of this sort can suggest to students that science is more algorithmic and certain than it actually is in professional practice. Indeed, in a review of four hundred and sixty-eight inquiry tasks in nine textbooks written for upper-elementary and middle schools and twenty-six inquiry tasks developed by researchers, Chinn and Malhotra (2002) concluded that the 'epistemology of many school inquiry tasks is antithetical to the epistemology of authentic science' (p. 175; emphasis added). Such a conclusion, moreover, suggests that students often 
do not - paradoxically — get to 'do science' in school science. This, indeed, appears to be the case in that most beginning student-teachers state that, in their previous educational experiences, they have rarely, if ever, conducted scientific inquiries for which they had significant responsibility for procedures and conclusions (Windschitl, 2003).

School science programmes that prioritize teaching and learning of 'science', at the expense of learning 'about science' and to 'do science', are seriously compromising students' opportunities to develop comprehensive scientific and technological literacy. Collins, Osborne, Ratcliffe, Millar and Duschl (2001) state, for example, that an 'overemphasis on "what we know" at the expense of "how we know" results in a science education which too often leaves students only able to justify their beliefs by reference to the teacher as an authority' (p. 4). Such conditioned dependence on authorities may jeopardize students' potential autonomy in societal decision-making involving science and technology. As consumers of products and services generated using science and technology, for example, poor conceptions of the nature of knowledge generation in these fields may limit the extent to which they can critically evaluate the merits of such products.

Those associated with school systems, therefore, need to promote more appropriate emphases on learning: 'about science' and to 'do science', in addition to its traditional emphasis on learning 'science'. One approach is to encourage and enable students to conduct student-directed, open-ended (Lock, 1990) science and technology projects. Through these types of projects, students can learn some 'science', although not, necessarily, concepts prescribed for them in curricula (Hodson, 1996). They also can develop more realistic conceptions 'about science', although these should be supplemented with more teacher-directed approaches (Abd-El-Khalick \& Lederman, 2000). Although teachers should provide some more direct scaffolding regarding problem solving approaches in science and technology (e.g. Bencze, 2000), student engagement in student-led science and technology projects is necessary for them to develop scientific and technological connoisseurship - that is, unique sets of capabilities that enable people to solve problems in specific contexts (Hodson, 1996). Such connoisseurship is useful for science-based careers and for use of science in everyday life (Aikenhead, 2005; Duggan \& Gott, 2002). Accordingly, governments have officially sanctioned efforts to help students to develop expertise in scientific inquiry and related historical, sociological and philosophical perspectives (e.g. DfEE, 1999; NRC, 2000). 


\section{STUDENT PARTICIPATION IN SCIENCE FAIRS}

Among approaches that may be useful for promoting student-directed, open-ended science and technology project work are science fairs. These are events at which students' mathematics, science, and/or engineering (MSE) projects are evaluated and celebrated. Students typically carry out projects either within or outside of the context of their schooling and, then, compete at the school level for the right to exhibit summaries of their projects at a regional fair and, if successful, they may then compete for awards at a national fair. If they are among the most successful nationally, they can then participate in an international science and engineering fair.

Although science fairs have been held for many decades and despite some support for them from educators (e.g., Grote, 1995), there is a remarkable paucity of peer-reviewed research findings about them (Abernathy \& Vineyard, 2001; Czerniak \& Lumpe, 1996; Yasar \& Baker, 2003). Of the studies that have been conducted, a few have cast fairs in a positive light. Some studies suggest, for example, that student participation is motivated, in part, by being able to learn something new (Abernathy \& Vineyard, 2001; Czerniak \& Lumpe, 1996). There is some evidence, for instance, that students' project presentations can help scaffold them towards a more informed use of scientific discursive practices (Gomez, 2007). Indeed, many students have managed to nurture the same project over a few successive science fairs and, in the process, have gained much facility with discourse practices in the sciences (Pyle, 1996; Bencze \& Bowen, unpublished data). Although research reports about science fairs are relatively rare, one can imagine other important learning outcomes from participation in them; such as: deeper understanding of subject matter knowledge (especially topics of their inquiries); awareness of some characteristics of science, including its competitive nature; and, technical skills, such as measurement techniques.

Most studies of science fairs have been somewhat critical of them. There is some doubt, for example, as to the extent to which some students may be motivated to conduct and exhibit projects given that, in many jurisdictions, participation in science fairs is mandatory (Abernathy \& Vineyard, 2001; Bowen, unpublished data; Bunderson \& Anderson, 1996; Czerniak \& Lumpe, 1996). Research results are inconclusive, however, in terms of effects of participating in a fair on students' attitudes towards science - although some authors speculate that the extra time spent with parents to complete science fair projects and displays may be viewed positively (Bunderson \& Anderson, 1996; McDonough, 1995; Sumrall \& Schillinger, 2004).

Among the more contentious issues about science fairs is their competitive nature; particularly in terms of their tendency to praise 'winners.' Some argue that, although competition with the possibility 
of praise associated with winning may be a motivator for student participation, it may also compromise students' intrinsic motivation for actually conducting projects — such as being inherently curious about topics, and enjoying the challenges of problem solving (NSTA, 1968; Paley, 1971). Competition may, by its very nature, also discriminate against students who, regardless of their inherent abilities, may not have access to various kinds of resources that enhance their projects and/or displays. Additionally, there appears to be a privileging of older students whose projects are greatly supported through access to a university (Gifford \& Wiygul, 1992), perhaps unsurprising given the positive role that mentors have been found to play in project success (Czerniak \& Lumpe, 1996; DeClue et al., 2000; Marsa, 1993; Rodia, 2004; Ryan, 2000). Related to this, there are some suggestions (Bunderson \& Anderson, 1996; Gifford \& Wiygul, 1992), although it is not unanimous (Pyle, 1996), that students with access to great financial resources may have a competitive advantage over other students. Indeed, these studies and others — such as those by Bellipanni (1994) and Jackson (1995) — suggest that students who have greater cultural and economic capital to draw upon stand a greater chance of success. Perhaps such competitive advantages may explain results from some studies which found that many students find the competitive nature of fairs unpleasant (Chiappetta \& Foots, 1984; Yasar \& Baker, 2003).

Given the competitive nature of fairs, it is, arguably, important that the judging process be fair and effective. However, some research cast doubt on the character of some judging. It is apparent that some judges often bring — perhaps not unexpectedly — certain biases to their evaluations (DeRosier, 1997; Grobman, 1993; Grote, 1995; McBurney, 1978), including issues such as insufficient backgrounds and biases towards one sort of project over another. For instance, there are reports that some judges actually discourage 'investigative projects' (Smith, 1980; p. 23) by younger children — despite suggestions that investigative designs are probably necessary for success for high school students at national and international levels (Pyle, 1996).

\section{RESEARCH METHODS}

\section{Research Context}

Although there has been some research relating to the nature of science fairs, much of it seems to focus on the nature of students' experiences in conducting projects and exhibiting summaries of them at fairs. Very little research about science fairs has focused on their relative position with regards to parts of societies that, directly or indirectly, sanction them. Accordingly, we sought to develop understanding about science fairs as they relate to the milieu surrounding them. 
The subject of our study was the national science fair in Canada, known as the Canada-Wide Science Fair (CWSF). This fair began in 1962 with 40 exhibits ${ }^{1}$, and is now a major week-long event involving about 450 students who have qualified for national-level competition after having competed successfully in local and regional fairs.

Research reported here involved studies of four successive national science fairs; that is: i) 2002 in Saskatoon, Saskatchewan, ii) 2003 in Calgary, Alberta, iii) 2004 fair in St. John's, Newfoundland and Labrador, and iv) 2005 in Vancouver, British Columbia. Information from websites relating to the 2006 (Saguenay, Québec), 2007 (Truro, NS), and 2008 (Ottawa) fairs also were included in the database. At each fair, students in grades seven through twelve from each province and territory are accompanied to the fair site by adult 'delegates', who act as chaperones and monitors of the science fair process. Once students' project displays are set up at the fair, they are judged by people working in fields of science, including as government and university scientists and those from the private sector. During the fair, students are provided with opportunities to participate in various tours of the local community and are treated to various celebratory events (e.g. a banquet in their honour). The week-long event typically culminates with an awards ceremony, followed by a dance.

\section{Data Collection and Analysis Methods}

To study the CWSF, naturalistic (Guba \& Lincoln, 1988) research approaches were taken, allowing conclusions to emerge from our studies. Related to this, qualitative, ethnographic research methods (e.g. Hammersley \& Atkinson, 1990) were employed. Data collected and analyzed, as described below, varied according to access ${ }^{2}$ we were able to obtain to various aspects of the fairs in different years.

- Webpage Materials: Public-domain information posted on websites (of the Youth Science Foundation and fair host city) for 2002-2008 fairs were collected, including: goals of the fair, the schedule of events, lists of tours and other non-competitive activities, descriptions of projects, including award winners, and sponsor information.

- Science Fair Documentary Material: Documentary material produced by organizers of fairs were collected (some via websites), including: 2003 CWSF Finalist Booklet; Information for 2003 CWSF Judges; electronic files of the 2003 and 2004 Gold Minds booklets (highlighting projects of all major

\footnotetext{
${ }^{1}$ The national science fair in the USA began twelve years earlier in 1950 (Bellipanni \& Lilly, 1999).

${ }^{2}$ Access to different aspects of the fairs varied according to permissions granted by the respective fair organizing committees. We had full access to the 2003 fair. For all fairs, data were obtained from sources in the public domain, including: Friday PM Awards Ceremony, Saturday AM Public Viewing, and fair and organizers' websites.
} 
awards winners); an electronic copy of the 2004 fair exhibit area floor plan; and, a 2-page document providing information for potential sponsors of the 2004 fair.

- Students' Written Reports: From the 2003 CWSF, a 100-word abstract for each of the 360 projects and a 5-page final report for 152 projects were collected. During Public Viewing, we also could view students' log books (journals of their projects).

- Transcripts of Semi-structured Interviews: During the 2003 CWSF, students involved (singly or in pairs) in 18 projects were interviewed (for about 30 minutes each), using four basic questions/requests: i) Please describe the main features of your project (e.g. purposes, methods, results), ii) What kind of help did you get in doing this project?, iii) When you planned your project, did you have a good idea of your results and conclusions? Explain, and iv) How did your project compare to what scientists/technologists usually do? The same protocol was repeated for seven Senior projects (individuals or pairs) during the Public Viewing session of the 2005 fair. Interviews were audio-recorded and later transcribed.

- Visual Images: Many digital images, some available through websites, were collected. At the 2002 CWSF fair, we produced a video recording (of about 15 minutes) of the Keynote Address at the Awards Ceremony by a Canadian scientist and Chair of a private company. Digital still pictures of project display(s) for 313 projects also were produced. From the 2003 CWSF, we produced or collected the following digital still photographs (with numbers of pictures in brackets): the awards ceremony (21), including award winners in each category; project displays (360); team members from each of the provinces and territories (12); each award winner, in each of six divisions (e.g. Biology), three age groupings, and four award levels (Platinum, etc.) (72); a company representative speaking to award winners (1); fair banquet and subsequent dance (5); and, the display boards for each of the 18 projects for which interviews were conducted (59). A 20-minute video recording of highlights of the Awards Ceremony also was produced. From the 2004 CWSF fair, single photographs of 350 project displays were collected. From the 2005 fair, we collected six promotional video recordings, totally about 80 minutes in length, and we produced 48 digital still pictures and a 25-minute video of the 1-hour Awards Ceremony.

- Anecdotal Records: During the 2002, 2003 and 2005 CWSFs, written ethnographic field notes were collected during each fair. These field notes were kept in a hand-written journal and totaled about 1,500 words of text for each fair.

In preparation for qualitative analysis, we performed readability analyses on the five-page reports of the 15 projects studied most closely from the 2003 fair, using the average of two methods; that is, the: i) readability function in Microsoft Word ${ }^{\mathrm{TM}}$, Mac version 11.1 (found in the Spelling \& Grammar option 
of the Tools menu), which calculates a Flesch-Kincaid Grade Level and ii) Text Content Analysis Tool at UsingEnglish.com ${ }^{3}$, which calculates the Gunning Fog Index. We also independently evaluated 218 project abstracts from the 2003 fair in terms of the degree to which they cast MSE in a positive light. Projects were deemed 'positive' (+) if, for example, results worked out as predicted or if a successful design was developed; projects were deemed 'negative' (-) if, for example, the investigation uncovered some adverse effects of mathematics, science and engineering; and, projects were deemed negative and positive if, for example, the project was successful in solving some problem associated with MSE. Examples of projects in each of these categories are:

- Positive: 'Go-with-the-flow is designed to automatically control the water level of an active river system. This prototype uses two different mechanisms to activate the position of two sluice gates. The system can sense the water level and based on this feedback, can automatically adjust the gate position proportionally';

- Positive and negative: 'Many consumers today are concerned about the use of synthetic, chemical preservatives in food and their effects on human health. Our experiment investigated whether Lactic Acid Bacteria can be a more effective preservative than even other natural preservatives, such as vinegar and salt. The results were quite favourable'; and,

- Negative: 'The aim of this study was to investigate the claims for antibacterial dish washing liquids that they kill $99.9 \%$ of bacteria. Contaminated cutting boards were cleaned with various cleaners and swabbed for bacterial growth. The results were, for the most part, far from their claims of killing virtually all the bacteria' (YSF, 2003d).

Results of these analyses are provided in Table 1. In examining these abstracts, we also noticed that many appeared to have commercial applications. We, therefore, independently coded the 2003 abstracts for whether or not they appeared to us to have commercial potential. A typical project with significant commercial potential was described as follows: 'My project tested if bark from sawmills could be used to produce methane gas. I had three variables as follows: fine particles of bark, small chips and large chips. I found that bark works very well to produce methane gas and the fine powder worked the best'. The description of a typical non-commercial project was: 'The power output of jumping grasshoppers was measured by videotaping grasshoppers jumping in front of a grid mounted on a wall. The power output per unit mass was found to be 6-106 times greater for a grasshopper than for a horse. An exciting discovery was the observation of gymnastic tail-over-head flips during jumps, which has not been previously seen' (YSF, 2003d). Results of this analysis are provided in Table 2.

\footnotetext{
${ }^{3}$ Located at: http://www.usingenglish.com/resources/text-statistics.php
} 
Reviewing all of these sources, each of us then independently and repeatedly coded all data for relevant categories, and then refined, developed and related them to enable development of encompassing themes - using constant comparative methods, based on constructivist grounded theory (Charmaz, 2000). HyperResearch (Version 2.04) qualitative analysis software was used to assist with coding and analyses. Codes, categories and themes were then negotiated between us, based on the principle of 'interpretive zone' as a 'place where multiple viewpoints are held in dynamic tension as a group seeks to make sense of fieldwork issues and meanings' (Wasser \& Bresler, 1996, p. 6). Our analyses of video data, grounded in interaction analysis (Jordan \& Henderson, 1995), were based on the assumption that understanding and reasoning is observable in the form of socially structured and embodied activity (Garfinkel, 1967). Alternative theoretical stances were employed, including communities-of-practice theory (Wenger, 1998), and various research approaches were used, including induction (generalizing from data, while recognizing its theory-basis), abduction (applying theory to explain data) and deduction (comparing results to those predicted) approaches. Member checks with participants were then conducted to help ensure trustworthiness of claims, each of which was based on a minimum of three corroborating data sources (Guba, 1981).

\section{RESULTS AND DISCUSSION}

\section{Preamble}

Visitors to the Canada's national science fair may develop positive impressions of this event. The student participants are generally quite bright, enthusiastic, often articulate and poised, and have conducted very interesting and often challenging mathematics, science and/or engineering projects. People helping to facilitate the fair also are enthusiastic, polite and friendly and, given their mostly volunteer status, generous in many ways. From our observations of student engagement and conversations during the CWSF's we attended, we concluded that students greatly enjoyed both the formal and informal activities planned by the organizers of the fair.

We were also impressed with many aspects of science literacy demonstrated by students participating in the CWSF. There were, for instance, numerous indicators that students participating in the CWSF had appropriated canonical science practices in communicating their findings, thus suggesting that, apart from any science content that participation helped them learn, they also effectively

\footnotetext{
${ }^{4}$ HyperResearch Version 2.0 [Computer Software] (1999). ResearchWare, Inc. London: Scolari Sage Publications Software.
} 
learned other aspects of science literacy. For instance, use of graphs and inscriptions often is considered a central part of constructing scientific claims. Our analysis of a sample of photographs of one hundred randomly chosen project displays indicates that students understand the centrality of inscriptions (both graphical and tabular; Latour, 1987) in representing data. This analysis found that of those one hundred posters, ninety-nine of them used either or both tables and graphs with a total of 469 graphs and 165 tables being present in those 99 posters, a usage frequency that rivals that found in posters and talks presented by scientists at conferences (Bowen \& Hembree, 2005). We also noted that in their project logbooks and reports (required by the science fair) students frequently attended to claims-making practices recommended in science education literature, especially involving argumentation and concepts of evidence (Gott \& Duggan, 2007) — in that their final claims were often supported through the use of replication, triangulation, and often statistical analysis, with their findings embedded in a broader research literature (journals, books, etc.) such as would be the case in research papers in specific science disciplines. From the use of inscriptions in their arguments and the rhetorical and evidentiary strategies, we conclude that students have learnt many of the normative practices of science investigation.

While our experiences with successive fairs support our observations of both the development of science literacy skills in the projects and the engagement and enjoyment by the participants in the science fair itself, we nonetheless feel that there are some important issues about the representations of science and the role it serves in society that remain problematic. In the sections that follow, we discuss these issues — using data from several national science fairs ${ }^{5}$ — in terms of three overall themes; that is, Access, Image, and Recruitment. Possible explanations for these phenomena are explored in the Discussion and Conclusions section below.

[Insert Figure 1 about here; Caption = Science Fair Competitiveness (YSF, 2003c).]

\section{Access}

Qualifying for the national science fair in Canada is a lengthy and demanding process that, in effect, reduces the number of science fair participants to the 'cream of the crop' - as illustrated in Figure 1. In the words of the Youth Science Foundation (YSF, 2003c), the group that facilitates organization of the national fair in Canada, the national fair is:

\footnotetext{
${ }^{5}$ It should be noted that fair organizing committees generally copy the overall framework for the fair structure from the previous year's organizing committee. Every year, for example, judging occurs on the Tuesday and Wednesday of the week, followed by participant tours of the local area on Thursday and then the awards ceremony and dinner on the Friday. This means that, although we may have used data from one particular fair to illustrate a theme, we could have used data from any of the other fairs to support the same claim.
} 
the largest extra-curricular youth activity related to science and technology in Canada, gathering our best young minds together. Each year, some 450 [about $2 \%$ of the maximum] top young scientists [students] are chosen to compete from the ranks of some 25,000 competitors at nearly one hundred regional science and technology fairs staged across the country. These elite participants compete in six divisions and three age categories for medals and other prizes worth approximately $\$ 250,000$ (p. 7).

There were, indeed, significant signs of most participants' elite status. For instance, students appeared to dress and speak well, and many seemed to have access to relatively expensive technologies, such as cell phones and laptop computers. It was not unusual, according to interviews, for students to spend hundreds of dollars on preparing their display — and some even utilized graphic design firms to maximize their impact. Some students referred to spending money on their display as an investment that they would recoup from the prize money that they expected to receive as a consequence of having a professionally designed display. During our interviews, we were highly impressed with the advanced level of students' discourse regarding what often were quite complex projects. Although we both hold M.Sc. degrees in the life sciences, we found that we frequently had to ask supplementary questions to clarify our understanding of students' explanations of concepts in our field. Students' content and level of speech was often quite sophisticated. A typical conversation, involving a ninth-grader (A) who won a silver medal (2003), was:

A: What I did was I made a computer program using language in Visual Basic. Basically what this program does is that it analyzes DNA sequences. It would transform its DNA sequence from a text file into graphical image like this one over here.

L: Slow down. What was the purpose again? Just if you want to talk a little bit around the purpose. You wanted to develop this program to analyze DNA sequences. Where did you get the idea.

A: For the last few years, I have been researching into different papers on DNA and my brother has been doing science for the last few years. My brother used to work at Sick Kid's and Mount Sinai [hospitals].

L: What position? 
A: As a [inaudible]. He's only in grade 12 this year. He was working with them in grade 9 through grade 11. And he did his project about using Visual C Plus files and he made a project about [inaudible] and he competed at the Canada-wide and he won here. And in the world [fair] he came third. So after everything last year, he actually gave me the idea. Many scientists these days are trying to research more about DNA and trying to analyze them in terms of the base pairs. So then he said, maybe you could make a program that would be beneficial ...

This led us to conduct readability analyses of reports of the students we interviewed in 2003. Our analyses indicated that, while their actual average grade level was 9.9, the readability scores of their reports suggests that their average grade level was 11.5. Considering the level of expertise in communicating ideas that students qualifying for the national science fair exhibited, it may be, as Lemke's (2001) discourse analyses of school students' language practices indicate, that many of these students were relatively rich in cultural capital (Bourdieu, 1986) — which often is derived from being raised in middle- and upper-middle-class families. In support of this claim, our interviews of the 22 students involved in 15 projects at the 2003 fair revealed that all of them had home computer(s) with internet access and they stated that they used these for much of their work. In 2005, only one student/project out of the seven interviewed indicated that he had a dial-up connection, while the rest had high-speed internet access at home. Associated with such cultural capital, it also appeared that students had significant social capital; that is, a person's access to a advantageous social network (Bourdieu, 1986). Students in 10 of the 15 projects, for instance, had access to university-based (9) or private laboratories and, as well, assistance from personnel working in the laboratories. One student, for example, noted that he used a laser-based instrument in his mother's laboratory (belonging to her company) to make measurements for his project. His father, an engineer and frequent science fair judge, also taught him about methods for science inquiry (e.g. control of variables) and statistical analysis (ChiSquare and t-Test). Similarly, a student at the 2005 fair used equipment and assistance from a technician to improve a fuel cell at laboratories of a private company at which her father was an engineer. Such personal resources appear essential for students, given that most indicated to us that their projects were conducted independent of school requirements or support - a finding supported by research elsewhere (Bellipanni, 1994; Jackson, 1995).

Given such strong communication skills, along with their access to various exclusive human and material resources, it is apparent that students qualifying for the national science fair in Canada had advantaged backgrounds. As the YSF states, these students are 'elite participants' (p. 7). The process 
leading up the national fair, therefore, may have sorted students partly based on their ability to conduct and report on projects in MSE but, as well, on their access to resources not, necessarily, available to all students. From the perspective of social practice theory, their involvement in science (and related disciplines, such as mathematics) may then be considered a form of preferential legitimate peripheral participation (Lave \& Wenger, 1991). It is peripheral because they are not quite core participants in practices of science but, nevertheless, is legitimate since they are functioning at a relatively high level of expertise. Additionally, it is preferential, because many of the students qualifying for the national fair appear to be members of middle-to-high socio-economic groups.

\section{Image}

Having survived the 'rigorous' selection process for participation in the national fair, students are, then, of course, subject to further intense scrutiny in order to determine winners of over $\$ 200,000$ worth of medals and prizes (refer to Figure 1). The overt criteria for this selection process are itemized in the judging forms used at the fair; that is:

i) Scientific Thought (45\% of total), which refers to the nature of the methods of design and analysis of the inquiry and/or design project,

ii) Creativity (25\% of total), which includes the novelty of the topic, methods and conclusions,

iii) Display (20\% of total), including its construction and dramatic value, and

iv) Report (10\% of total), including its clarity of wording and logic of presentation (YSF, 2003a, pp. 35-36).

Using these criteria, the most successful students/projects are granted Olympics-style awards of increasing value; that is: 'Honourable Mention', 'Bronze', 'Silver' and 'Gold' in each of six categories (e.g. Life Sciences, Engineering, etc.) and three age ranges (i.e. Junior $=$ grades $7 \& 8$; Intermediate $=$ grades $9 \& 10$; and, Senior $=$ grades $11 \& 12$ ). A few experts then re-judge the eighteen gold medalwinning projects and grant 'Platinum' awards to the best among them in each age group. From amongst these three projects, judges name one project 'Best-in-Fair'. Overall, the judging process reduces the approximately 300 (about 450 students) projects to about 20 projects deemed to be the 'best of the best' (YSF, 2003b, p. 4). In addition to receiving various awards, certificates and money, these projects/students were included in the document, Gold Minds, which is said to celebrate 'the significant accomplishments of those outstanding young scientists who drive themselves to the very top of 
[Canada's] science fair structure each year' (YSF, 2003c, p. 5). Gold Minds was widely distributed to members of the public, government and the business community, and others; and was freely-available on the website of the Youth Science Foundation.

[Insert Table 1 about here; Caption = PORTRAYAL OF SCIENCE IN STUDENT REPORTS AT THE CWSF.]

Selection of these ultra-elite projects/students for awards seems to be based on factors beyond the judging criteria outlined above, however. It was apparent, for example, that there was a tendency to select and award projects that cast mathematics, science and engineering in a positive light. As indicated in Table 1, at each award level (i.e. Honourable Mention $\rightarrow$ Gold), the percentage of the awarded projects that cast MSE in a positive light tended to be greater than those with both a positive and negative image which, in turn, tended to be greater than the percentage of projects casting MSE in a negative light. Large fractions of successful projects, for example, had apparently efficient methods for arriving at relatively certain conclusions, such as:

Effects of four diets on hen egg length, width, weight, and laying frequency were examined. Results indicated laying frequency differed with diet but egg size and shape remained constant for individual birds, suggesting a genetic link for these characteristics. Elementary mathematical analysis of the data confirmed these findings (Silver Medal).

Overall, about eight percent of the awarded projects appeared to portray MSE negatively, twenty percent of the projects seemed to have both positive and negative connotations and about seventy-two percent appeared to provide a positive image for MSE. Related to — and corroborating our conclusions about such positive portrayals, significant proportions of winning projects, according to our independent analyses, had some positive commercial potential, such as:

The project's goal was to simulate the brain's 'time-keeper' (circadian clock) using mathematical equations. The model accurately replicated circadian behaviour and made predictions of the effects of certain drugs on the clock. This has many applications in medicine and industry, especially concerning shift work, jet lag, and tranquilizer drugs (Gold Medal). 
As indicated in Table 2, although it was not particularly evident regarding gold medalists, approximately sixty-three percent of silver and bronze medal-winning projects at the 2003 national fair had significant commercial application. Projects without significant commercial potential were less likely to receive silver and bronze awards.

In addition to processes relating to judging, there were other phenomena associated with the fair that seemed to cast professional MSE in a positive light. Awards Ceremony speakers, for example, tended to speak in glowing terms about science. The keynote speaker of the awards ceremony at the 2002 fair, for instance, who was the CEO of a genomics company and former practising scientist, said (with great passion): 'There is hardly another area of human endeavour where the work that you [the students] will do is more important, the possibilities more exciting or the potential for humankind more beneficial than that of science' (emphasis added). In congruence with this sentiment, organizers of the awards ceremony of the 2003 national fair chose to periodically play (accompanied by 'catchy' music) a series of video clips of participating students' comments about science and science fairs that also cast MSE in a positive light; such as:

Engineering affects everything we do! So, it is very important'; Washing the dishes involves science; [Science] allows us to have electricity; [Science] allows us to make things easier [for humans], to have things funner [sic]. It's an opportunity to watch TV, to go on the computer. Without science, we'd have none of these things; Science makes the world go around!; Science makes the world turn, I guess; Technology is expanding very rapidly and there are a lot of problems we face. So, science often holds the answers for a lot of those. If you are involved in science, you get to get on the bandwagon and do a lot of the work [to solve problems]; and, We have to think of different things that are going to solve the world's problems today [all enthusiastically-stated].

Given the degree to which the national fair in Canada is supported by major private companies and publicly-funded universities, it stands to reason that they might benefit from such positive portrayals of MST as those described above. Indeed, it is apparent that, through the process of 'synergy' (Klein, 2000), in which businesses link positive phenomena in society with their logos/brands, corporate and university sponsors of the national fair may associate themselves with everything that is 'good' about the students and their projects, particularly for the award-winning projects/students. Through our attendance at the 2002, 2003 and 2005 national fairs and through our analysis of data from the websites for the 2002 through 2008 fairs, it was quite evident that the level of 'visibility' of particular companies and universities was significant. Logos are typically placed in various strategic locations associated with 
the science fair selection process and its products. Students from different provinces wear, often while being judged and while being photographed in front of their displays, 'team' jackets that prominently display the logos of sponsoring businesses and universities (often more prominently than the corresponding provincial logo). Similarly, various volunteers - e.g. for distributing programs and for tending to security matters — often wear 'T-shirts' and/or jackets containing sponsors' logos. These items of clothing were donated by the respective sponsors. Most, if not all, publications associated with the fair, including those for judges, volunteers, student participants, those attending awards ceremonies and banquets, also contain numerous logos. Prominent displays of logos also can be found in Gold Minds (YSF, 2003c, 2004a), in which a large logo is associated with each winner of a gold medal, platinum award and Best-in-Fair award. Related to this, sponsors' logos were prominent during the various tours and social events in which students participated during the week of the fair. With few exceptions, it was not possible to stand in any part of the facility in which the CWSF was being held and not see the corporate logos of sponsors, nor does any of the distributed literature lack for these logos. On the floor with the student projects there also exist sponsor tables distributing various types of literature, and many also distributed toys, pencils, pens, erasers and so forth - all branded with the corporate name and/or logo, to participating students and other children attending the science fair.

A very dramatic example of this sponsor advertising occurred during the awards ceremony at the 2003 fair (which we also witnessed at other fairs). The stage for the event was arranged to resemble a giant science fair display board, with the awards being distributed on centre stage, while large video screens on the each side of the display continually flashed logos of the sponsoring companies and/or universities. A particularly fascinating aspect of this was that, as photographs of prize-winning students standing beside their project displays were repeatedly flashed in a small window on the video screens, logos of companies and universities that sponsored the awards in each group (e.g. Junior Life Sciences) remained in place. This allowed companies/universities to associate themselves with large groups of successful projects. All of this arguably represented a form of advertising for the sponsors, allowing them to 'say', through their logos, that their companies and/or institutions are youthful, enthusiastic, idealistic and pure.

Overall, therefore, it is apparent that the CWSF, including its awards ceremony, may represent an excellent promotional campaign for professional (university- and business-based) mathematics, science and engineering (MSE). For individuals — including the student participants, their parents/guardians, delegates, personnel from universities and businesses, and members of the general public — having some contact with the CWSF, professional science and engineering might appear to be relatively sophisticated, systematic and successful (particularly in terms of their commercial rewards) and 
relatively beneficial to individuals, societies and environments.

\section{Recruitment}

[Insert Figure 2 about here; Caption = Science Fair Semiotic Success Trajectory.]

Apparently associated with positive portrayals of MSE provided by the national fair is a wellorchestrated recruitment drive; to attract the best students into programmes of certain universities and, eventually, into careers with certain companies. One indication of this was what we call a semiotic success trajectory. As seen in Figure 2, projects at the 2004 fair (as in others) were arranged in a way that might suggest a natural trajectory for students from elementary schools, through secondary schools and universities to business careers in mathematics, science and engineering (as represented in (Sponsor's [sic] Row').

[Insert Table 3 about here; Caption = FEES FOR SERVICE AT THE CWSF.]

To be involved in such recruitment, universities and companies were required to provide financial support for the fair. The more money paid, the greater their exposure to those they might influence. As illustrated in Table 3, there were five levels of 'visibility' for which potential sponsors of the 2004 fair could pay; that is, i) 'Supporters' $=<\$ 5,000$, ii) 'Bronze' $=\$ 5,000+$, iii) 'Silver' $=\$ 10,000+$, iv) 'Gold' $=\$ 25,000+$, and v) 'Platinum' $=\$ 50,000+$. A sixth level of access, the value of which we were not privy, was reserved for sponsors of students competing at the international science and engineering fair (YSF, 2004b, pp. 12-13). Clearly, those companies/universities that were willing and/or able to spend the most money, could — potentially — have significant influence on judging (especially when spending $\$ 10,000$ or more to allow sponsor representatives to serve as judges of all projects), people's conceptions of science and engineering (via images established by students, for example, as discussed above) and students' study and career choices.

A key element of universities' and companies' strategy for moving students along the semiotic success trajectory appeared to be significant commodification - a process involving conversion of a phenomenon into commodities (units of economic exchange). Frequently, this process involves substantial reductionism; that is, conversion of a relatively complex phenomenon into a simpler, perhaps more manageable, one. Students' levels of 'achievement' (which, in science, as in many/most endeavours, can be highly complex and situational), for instance, were translated into specific reductive categories; that is, awards that were linked to particular currency values. For example, at the 2003 
national fair, projects/students' performance at each of the following levels was equated with a corresponding monetary value (numbers in brackets refer to numbers of awards): Gold medal (18) = $\$ 1500$ + certificate; Silver medal $(36)=\$ 700$ + certificate; Bronze medal $(54)=\$ 300+$ certificate; Honourable Mention (180) = certificate (YSF, 2003a, p. 18). The monetary incentives for reaching the top levels of 'achievement' at the national fair are even more lucrative:

[Corporation X] generously sponsors the Grand Awards. Each Platinum Award includes \$5,000 cash and a distinctive presentation award. The Best-in-Fair Award includes an additional \$10,000 cash and presentation award. The Best-in-Fair project receives a total of $\$ 16,500$, not including any Special Awards. This is one of the most valuable and prestigious youth awards in Canada (YSF, 2003a, p. 19).

Organizers and others associated with the fair, moreover, frequently reminded people of the monetary benefits of science fair participation and success. They claimed that rigour in student achievement and in judging is critical because of the money at stake: 'With almost 500 young scientists [students] competing for over $\$ 360,000$ in prizes and scholarships, rigorous judging is a critical aspect of the fair' (YSF, 2004a, p. 4). Apparently, the organizers also felt that, if the money involved at the national fair were not enough, perhaps the monetary rewards at the international science and engineering fair would motivate students to participate in fairs:

The [Corporation] International Science and Engineering Fair [ISEF] is the world's largest precollege/university science fair. It brings together over 1300 young science pioneers [students] from more than 40 countries to share ideas, showcase cutting edge science[, mathematics \& engineering] and compete for over \$3 million US in awards and scholarships (YSF, 2004a, p. 28).

Team Canada participants have enjoyed a tremendous success rate at the international level. This year, twenty of Canada's brightest young minds brought home over CDN\$100,000 in prize money at the $54^{\text {th }}$ [Corporation] International Science and Engineering Fair (ISEF) 2003' (YSF, 2003c, p. 35).

In the end, the system equating 'success' with financial rewards seems to be self-perpetuating, as the most successful students in the fair are then, apparently, used as an enticement for further sponsorship: 'Judging of the Grand Awards is done by the CWSF 2003 Grand Awards Judging Committee. Its job is to pick the best of the best to meet the national and international sponsorship needs' (YSF, 2003b, p. 4). 


\section{SUMMARY AND CONCLUSIONS}

The Youth Science Foundation (YSF, 2003a), which facilitates organization of Canada's national science fair, states that purposes of the event are to:

bring together Canada's top young scientists [students], to benchmark personal scientific and technological achievement against the achievements of peers and to enjoy a positive science and social experience ...[and] ... to expose students in the geographic area of the CWSF to peer role models - the best young science and technology minds in the country (p. 2).

While none of this seems incongruent with our research, there appear to be some significant broader generally unstated - societal consequences associated with the national science fair. Based on our study of several national fairs, including being present for three of them, it is apparent that this event represents an opportunity for corporations and universities to associate themselves with bright and enthusiastic young people whose projects in mathematics, science and engineering generally shine a positive light on these fields and who, through sponsorship efforts, may be convinced to pursue careers in these fields - preferably in association with the sponsoring corporations and universities.

There may be many feasible explanations for the fair's characteristics. However, statements made by the Youth Science Foundation suggest that the nature of the fair may, indirectly, be tied to the global economic system. In several publications, they refer to the need for Canada to be competitive in the global economy — such as in its Mission statement: 'YSF Canada engages and supports youth innovation through project-based science and technology, aiding the development of skills and knowledge for excellence in a global economy' (YSF, 2003a, p. 1). Similarly, many sponsors of the fair refer, in various ways, to the need to promote global economic competitiveness. Each day during the 2003 fair, for example, students were invited to participate in a draw for a book sponsored by the Canada Foundation for Innovation - a private corporation set up by the Canadian government 'to deliver programs that focus on Canada's needs and that enable its researchers to compete in the global, knowledge-based economy’ (CFI, 2005).

An orientation in support of a country's global economic competitiveness is not unexpected and, perhaps to a great extent, unavoidable. Many academics (e.g. Bakan, 2003; Carter, 2005; Gabbard, 2000a; Martin \& Schumann, 1997; McLaren, 2000; McMurtry, 1999) suggest that much of the world is being greatly influenced by global economization — a process that 'subordinates all other forms of 
social interaction to economic logic and transforms non-material needs, such as education, into commodities' (Gabbard, 2000b, p. xvii). Often, the system's goals are to promote large-scale, globalized, rapidly-repeating, for-profit production and consumption of goods and services.

Particularly in the new 'knowledge economy', for-profit production and consumption of goods and services is greatly dependent on the work of relatively few symbolic analyzers (those who can analyze and manipulate symbols, including words, numbers and visuals) - such as mathematicians, scientists and engineers (e.g. Lankshear, 2000). These elite workers are the knowledge producers of society; those who, often on behalf of business and industry, develop and manage mechanisms of production and consumption of goods and services. It seems clear from data in the study reported here that the overall science fair process - as illustrated by the schematic in Figure 1 - functions as a filtering system for selecting the most gifted students for potential enrolment in sponsoring universities and, eventually, for jobs as knowledge workers with sponsoring businesses. This selection process appears - according to our data analyses — to favour students who possess significant cultural and social capital. Highachieving students at the fair seemed to, for example, speak at levels beyond their grades in school and have access to various advantageous human and material resources. Selecting for such students appears to fit within the neoconservative agenda that often is associated with global economization; that is, an agenda that 'works to preserve traditional forms of privilege ...' (Carter, 2005, p. 571). Such exclusivity appears to challenge statements made by the Youth Science Foundation, which claims that science fairs make 'project-based science accessible to young Canadians with an interest in science' (YSF, 2004a, p. 3; emphasis added). Our research suggests that some access to project-based science may require more than interest. Students can benefit from being a member of a higher socio-economic class.

Associated with neo-conservatism in economization is neo-liberalism - an ideology that promotes maximal for-profit production and consumption of goods and services and, in the process, '... "marketizes" everything, even notions of subjectivity, desire, success, democracy, and citizenship, in economic terms ... (Carter, 2005, p. 571). In this light, much of the national science fair in Canada can be understood. At many fairs, it is relatively easy to see a synergistic relationship between the fair and sponsoring universities and businesses. Sponsors' logos are nearly ubiquitous, adorning participants' clothing, signs throughout the exhibit area and in prominent places during the awards ceremony. Whether or not it was consciously planned, diffusing into these logos appeared to be a brand that said, semiotically, that mathematics, science and engineering are youthful, bright, enthusiastic, methodologically honest, reliable and valid, and that their products are beneficial to individuals, societies and environments. Through such branding, sponsors' products may be easier to market. To assist in this market orientation, however, the fair also appeared to help to normalize commodification; 
that is, the transformation of phenomena that many would consider too valuable or too complex and indescribable (e.g. involving tacit elements) into units of exchange-value, entities that can be conveniently bought and sold (usually involving a currency) (McMurtry, 1999). At Canada's national science fair, there were numerous and significant examples of such counter-intuitive commodity generation - many of which are itemized in Table 3. For example, time spent talking to all students (e.g. through judging) and, most importantly (i.e. in terms of cost), to elite students (e.g. 'Special access to CWSF Award winners') were sold. These are typical transformations of social relations into commodities, phenomena that, in democracies, should be more freely available to all. Relevant to this commodification process, competitive, for-rewards science fairs may, arguably, cause students' motivation for involvement in project work to become much more extrinsic than intrinsic (based on qualities inherent to project work) — because of financial rewards associated with 'achievement'.

Findings from research reported here raise some challenging questions about science fairs. What, if anything, should be changed about national science fairs? Should they be made more participatory, somehow involving students with various levels of cultural and social capital? Should they be less competitive; more about celebrating diversity in students' mathematics, science and/or engineering projects than about evaluating them? Should support for them be made more public than private? Indeed, should they become more closely tied to schools, so that students conduct projects as part of their curricula and then exhibit them in a school-based context? We wonder, at the end of the day, if the overwhelming corporate promotion is in the best interests of the participating students, or whether it significantly disrupts their understanding of the nature of science and why one might consider pursuing science as a career. The considerable number of projects that fulfill an economic purpose (solving a problem with a marketable solution as opposed to understanding relationships in the world) are related to this concern. Ultimately, we could ask whether or not science fairs should be tied so closely, as indicated by the data and interpretations here, to promotion of a highly competitive and globalized knowledge-based economy. Answers to such questions are clearly not easy, but it may be that such questions are not being discussed by many associated with science fairs. Our study indicates that the national science fair in Canada has a long tradition and that organizers tend to repeat many of its characteristics. Public funding tends to be limited and project work tends to not be a prominent part of school science systems' curricular and instructional traditions. Moreover, the global economic system appears to continue to have significant influence over public and personal decision making. Nevertheless, findings and conclusions here may serve as impetus for further thought, study and action regarding student-led project work and associated dissemination efforts. 


\section{REFERENCES}

Abd-El-Khalick, F., \& Lederman, N. G. (2000). Improving science teachers' conceptions of nature of science: a critical review of the literature. International Journal of Science Education, 22(7), 665701.

Abernathy, T. V., \& Vineyard, R. N. (2001). Academic competitions in science: What are the rewards for sudents? The Clearing House, 74(5), 269-276.

Aikenhead, G. S. (2005). Science-based occupations and the science curriculum: Concepts of evidence. Science Education, 89(2), 242-275.

Bakan, J. (2003). The corporation: The pathological pursuit of profit and power. Toronto: Viking.

Bellipanni, L. J. (1994). The science fair experience: Profile of science fair winners. ERIC Document Reproduction Service No. ED 395793.

Bellipanni, L. J., \& Lilly, J. E. (1999). What have researchers been saying about science fairs? Science and Children, 36(8), 46-50.

Bencze, J. L. (2000). Procedural apprenticeship in school science: Constructivist enabling of connoisseurship. Science Education, 84(6), 727-739.

Bourdieu, P. (1986). The forms of capital. In J. Richardson (Ed.) Handbook of theory and research for the sociology of education (pp. 241-258). New York: Greenwood Press.

Bowen, G. M., \& Hembree, P. (2005, March). Participating in inquiry with field scientists: The development of discursive claim construction by practicing teachers. A paper presented at the annual conference of the National Association for Research in Science Teaching, Dallas, TX.

Bunderson, E. D., \& Anderson, T. (1996). Preservice elementary teachers' attitudes toward their past experience with science fairs. School Science and Mathematics, 96(7), 371-377.

Canada Foundation for Innovation [CFI] (2005). Accountability, Web Address: http://www.innovation.ca/about/index.cfm?websiteid=291. Ottawa: CFI.

Carter, L. (2005). Globalisation and science education: Rethinking science education reforms. Journal of Research in Science Teaching, 42(5), 561-580.

Charmaz, K. (2000). Grounded theory: Objectivist and constructivist methods. In N. K. Denzin \& Y. S. Lincoln (Eds.) Handbook of qualitative research (pp. 509-535). Thousand Oaks, CA: Sage.

Chiappetta, E. L., \& Foots, B. K. (1984). Does your science fair do what it should? The Science Teacher, 51(8), 24-26.

Chinn, C. A., \& Malhotra, B. A. (2002). Epistemologically authentic inquiry in schools: A theoretical framework for evaluating inquiry tasks. Science Education, 86(2), 175-218. 
Collins, S., Osborne, J., Ratcliffe, M., Millar, R., \& Duschl, R. (2001). What 'ideas-about-science' should be taught in school science? A Delphi study of the expert community. Paper presented at the annual conference of the American Educational Research Association, April 10-14, 2001, Seattle, WA.

Czerniak, C. M., \& Lumpe, A. T. (1996). Predictors of science fair participation using the theory of planned behaviour. School Science and Mathematics, 96(7), 355-361.

DeClue, M. E., Johnson, K., Hendrickson, H., \& Keck, P. (2000). Stimulate high school science fair participation by connecting with a nearby college. Journal of Chemical Education, 77(5), 608609.

Department for Education and Employment [DfEE] (1999). Science in The National Curriculum for

England. London: Department for Education and Employment and Qualifications and Curriculum Authority.

DeRosier, W. R. (1997). A critical assessment of science fair judging. Unpublished master thesis, University of Saskatchewan, Saskatoon.

Désautels, J., Fleury, S. C., \& Garrison, J. (2002). The enactment of epistemological practice as subversive social action, the provocation of power, and anti-modernism. In W.-M. Roth \& J. Désautels (Eds.) Science education as/for sociopolitical action (pp. 237-269). New York: Peter Lang.

Duggan, S., \& Gott, R. (2002). What sort of science education do we really need? International Journal of Science Education, 24(7), 661-679.

Eisenhart, M., Finkel, E., \& Marion, S. F. (1996). Creating the conditions for scientific literacy: A reexamination. American Educational Research Journal, 33(2), 261-295.

Gabbard, D. A. (editor) (2000a). Knowledge and power in the global economy: Politics and the rhetoric of school reform. Mahwah, NL: Lawrence-Erlbaum.

Gabbard, D. A. (2000b). Introduction: Spreading the secular gospel. In D. A. Gabbard (Ed.) Knowledge and power in the global economy: Politics and the rhetoric of school reform (pp. xiii-xxiii).

Mahwah, NL: Lawrence-Erlbaum.

Garfinkel, H. (1967). Studies in ethnomethodology. Engelwood Cliffs, NJ: Prentice-Hall.

Gifford, V. D., \& Wiygul, S. M. (1992). The effect of the use of outside facilities and resources on success in secondary school science fairs. School Science and Mathematics, 92(3), 116-119.

Gott, R., \& Duggan, S. (2007). A framework for practical work in science and scientific literacy through argumentation. Research in Science \& Technological Education, 25(3), 271-291.

Grobman, A. (1993). A fair proposition? The Science Teacher, 60(1), 40-41. 
Grote, M. G. (1995). Science teacher educators' opinions about science projects and science fairs. Journal of Science Teacher Education, 6(1), 48-52.

Guba, E. G. (1981). Criteria for assessing the trustworthiness of naturalistic inquiries. Educational Communication and Technology Journal, 29(2), 75-91.

Guba, E. G., \& Lincoln, Y. S. (1988). Naturalistic and rationalistic enquiry. In J. P. Keeves (Ed.) Educational research, methodology and measurement: An international handbook (pp. 81-85). London: Pergamon Press.

Hammersley, J., \& Atkinson, P. (1990). Ethnography: Principles in practice. London: Routledge.

Hodson, D. (1996). Laboratory work as scientific method: Three decades of confusion and distortion. Journal of Curriculum Studies, 28(2), 115-135.

Hodson, D. (1998). Teaching and learning science: Towards a personalized approach. Buckingham, UK: Open University Press.

Hodson, D. (1999). Science fiction: The continuing misrepresentation of science in the school curriculum. Curriculum Studies, 6(2), 191-216.

Jackson, E. L. (1995). A comparison of 1994 Mississippi Science Fair winners and nonwinners at the local, regional and state levels of competition. Paper presented at the annual meeting of the MidSouth Educational Research Association, Biloxi, MS, Nov. 10, 1995.

Jordan, B., \& Henderson, A. (1995). Interaction analysis: Foundations and practice. The Journal of the Learning Sciences, 4, 39-103.

Klein, N. (2000). No logo: Taking aim at the brand bullies. Toronto: Vintage.

Lankshear, C. (2000). Literacy. In D. A. Gabbard (Ed.) Knowledge and power in the global economy: Politics and the rhetoric of school reform (pp. 87-94). Mahwah, NL: Lawrence-Erlbaum.

Latour, B. (1987). Science in action: How to follow scientists and engineers through society. Milton Keynes: Open University Press.

Lave, J., \& Wenger, E. (1991). Situated learning: Legitimate peripheral participation. Cambridge: Cambridge University Press.

Lederman, N. G. (1999). Teachers' understanding of the nature of science and classroom practice: Factors that facilitate or impede a relationship. Journal of Research in Science Teaching, 36, 916929.

Lemke, J. L. (2001). Articulating communities: Sociocultural perspectives on science education. Journal of Research in Science Teaching, 38(3), 296-316.

Lock, R. (1990). Open-ended, problem-solving investigations - What do we mean and how can we use them? School Science Review, 71(256), 63-72. 
Marsa, L. (1993). Do high school science competitions predict success? The Scientist, 7(8), 21-22.

Martin, H.-P., \& Schumann, H. (1997). The global trap: Globalisation and the assault on prosperity and democracy (trans. P. Camiller). Sydney: Pluto Press.

McBurney, W. F. (1978). The science fair: A critique and some suggestions. American Biology Teacher, 40(7), 419-422.

McDonough, S. G. (1995). How parental support affects students' attitudes toward the science fair. ERIC Document Reproduction Service No. ED 390707.

McLaren, P. (2000). Che Guevara, Paulo Freire, and the pedagogy of the revolution. Lanham, MD: Rowman \& Littlefield.

McMurtry, J. (1999). The cancer stage of capitalism. London: Pluto.

National Research Council [NRC] (1996). National science education standards. Washington: National Academy Press.

National Research Council (2000). Inquiry and the national science education standards: A guide for teaching and learning, National Academic Press, Washington, DC.

Pyle, E. J. (1996). Influences on science fair participant research design selection and success. School Science and Mathematics, 96(8), 400-406.

Rodia, B. (2004). The scientific mentor. Teaching Pre K-8, 34(5), 56-67.

Ryan, L. J. (2000). Building and encouraging confidence and creativity in science. Masters Thesis, St. Martin's College. ERIC Document Reproduction Service No. ED457033.

Smith, N. F. (1980). Why science fairs don't exhibit the goals of science teaching. The Science Teacher, 47(1), 22-24.

Sumrall, W., \& Schilinger, D. (2004). Non-traditional characteristics of a successful science fair project. Science Scope, 27(6), 20-24.

Wasser, J. D., \& Bresler L. (1996). Working in the interpretive zone: Conceptualizing collaboration in qualitative research teams. Educational Researcher, 25(5), 5-15.

Wenger, E. (1998). Communities of practice. Cambridge: Cambridge University Press.

Windschitl, M. (2003). Inquiry projects in science teacher education: What can investigative experiences reveal about teacher thinking and eventual classroom practice? Science Education, 87(1), 112-143.

Yasar, S., \& Baker, D. (2003, March). The impact of involvement in a science fair on seventh grade students. Paper presented at the annual meeting of the National Association for Research in Science Teaching, Philadelphia, PA.

Youth Science Foundation [YSF] (2003a). Canada-wide Science Fair finalist booklet. Ottawa: YSF. YSF (2003b). Information for CWSF Judges. Ottawa: YSF. 
YSF (2003c). Gold minds/Esprits brilliants 2003. Ottawa: YSF.

YSF (2003d). Canada-Wide Science Fair project abstracts. Ottawa: YSF.

YSF (2004a). Gold minds/Esprits brilliants 2004. Ottawa: YSF.

YSF (2004b). Canada-wide Science Fair 2004: Information for Sponsors, 2003-2004. Ottawa: YSF. 